\title{
THE ENIGMA OF COMMUNITY \\ RESPONSIBILITY: ETHICAL \\ REFLECTIONS ON ACCIDENT \\ COMPENSATION
}

\author{
Richard Gaskins*
}

Lurking behind the familiar ACC principle of "community responsibility" are some core questions about what it means to be a community, and how responsibility is to be assigned. The original ACC blueprint took a distinctive approach to both terms - which was diluted in the process of implementation and further weakened in successive legislative amendments. And yet, mysteriously, over five decades, the language of "community responsibility" has remained at the centre of ACC policy discourse. Reflecting on ethical presumptions can clarify these evolving meanings, reframing key questions for future ACC debates.

\section{BACKGROUND}

The toll of personal injury is one of the disastrous incidents of social progress, and the statistically inevitable victims are entitled to receive a co-ordinated response from the nation as a whole. ${ }^{1}$

Nearly a half-century ago, a Royal Commission Report prepared the way for New Zealand's innovative Accident Compensation legislation (ACC). In that Report, a clever Judge made the case for fundamentally transforming a major field of private law, removing personal injury torts from the judicial process and replacing them with an alternative administrative scheme. Sir Owen Woodhouse concluded that the common law tort action for personal injury failed to meet the needs of a changing New Zealand society. His argument went beyond conflicts and anomalies within the

* Joseph M Proskauer Professor of Law and Social Welfare, Legal Studies Program, Brandeis University, United States of America. I dedicate this article to my friend and colleague, Bill Atkin. I have admired and learned from Bill for a good long time. Bill is an expert on many things, including ACC, and also notable for his willingness to address issues of values and ethics in his scholarship. He should not be held responsible for the approach taken here, but any symposium in his honour will inspire ethical reflection.

1 New Zealand Royal Commission of Inquiry into Compensation for Personal Injury Compensation for Personal Injury in New Zealand: Report of the Royal Commission of Inquiry (Government Printer, December 1967) [Woodhouse Report] at [1]. 
formal law, borrowing normative criteria from the larger domain of social welfare: "the whole field of inquiry opened up before this Commission is a social rather than a legal question". ${ }^{2}$ Under these circumstances personal injury tort law was beyond reform; it could be put to rest as soon as Parliament would enact a more adequate substitute.

New Zealand was the only country to move all the way through this transformation, although similar reforms were actively debated in other common law jurisdictions during the 1960s and 1970s - in North America, the United Kingdom and Australia (this last project guided by Sir Owen himself). The expanding critique of tort law, using extrinsic criteria of social welfare and social policy, originated with American legal commentators in the 1920s, prefigured by the 1880s musings of scholar/judge Oliver Wendell Holmes, Jr. ${ }^{3}$ Simultaneous with Woodhouse, some academic experts (including New Zealander Donald Harris and Canadian Terence Ison) ${ }^{4}$ were busy pounding stronger nails into the tort law coffin. To this day, the Woodhouse Report remains unsurpassed in its articulate affirmative vision: a concrete replacement scheme based on a short list of interlocking principles.

\section{A Introducing Community Responsibility}

Woodhouse called his leading principle "community responsibility". It was an ambitious stroke: at once a criterion for assessing the failures of traditional tort law, and a blueprint for constructing an alternative legal-political injury scheme: ${ }^{5}$

People have begun to recognise that the accidents regularly befalling numbers of their fellow citizens are due not so much to human error as to the complicated and uneasy environment which everybody tolerates for its apparent advantages. The risks are the risks of social progress, and if there are instinctive feelings at work today in this general area they are not concerned with the greater or lesser faults of individuals, but with the wider responsibility of the whole community.

From this bedrock notion Woodhouse derived several corollaries: the centrality of injury prevention and rehabilitation (missing from existing tort law), the need to compensate all losses (missing from current social welfare practices), procedural fairness and cost-efficiency. Over the past four decades, much has been written about New Zealand ACC and its troubled implementation, both legislative and bureaucratic. ACC moves up and down the political agenda every 10 years or

2 At [157]

3 See Leon Green The Rationale of Proximate Cause (Vernon Law Book Co, Kansas City, 1927). See also Green's later essay: Leon Green "Tort Law Public Law in Disguise" (1959) 38 Tex L Rev 257 and sources cited therein. For Holmes' early work, see Oliver Wendell Holmes Jr The Common Law (Little, Brown \& Co, Boston, 1881) at ch 3 .

4 Donald R Harris "The Law of Torts and the Welfare State" [1963] NZLJ 171; and Terence G Ison The Forensic Lottery (Staples Press, London, 1967).

5 Woodhouse Report, above n 1, at [89] (footnotes omitted). 
so, driven by ideological trends and practical performance issues. Remarkably, the community responsibility phrase itself has escaped the brunt of ACC controversies. With only minor exceptions, community responsibility is faithfully retained and respectfully incanted by friend and foe alike, arguing opposite sides of reform proposals. Today community responsibility survives as a largely hollow phrase, allowing defenders and critics to remain rhetorically connected to ACC ideals that have long-since grown opaque. This ritual embrace of community responsibility has had the effect of masking Woodhouse's bold ethical challenge. Starting with the initial implementation of ACC in the 1970s, the reforms of each decade have diluted and adapted that ethical framework to suit a wide variety of purposes - reflecting tacit changes, over these decades, in the common understanding of "community" and "responsibility".

Exploring the ethical dimensions of ACC means untangling our jumbled present. In part it means going back in time to assess how Woodhouse himself used this evocative term. But more important are the persistent puzzles and paradoxes surrounding the central terms "community" and "responsibility". The enigma of community responsibility comes from a dynamic tension in operational meanings, hidden beneath the surface of these two broad abstractions. Moving beyond historical and conceptual analysis, one reaches urgent questions about future generations in New Zealand: what will it mean to be a "community", and how will the main lines of responsibility be drawn? Revisiting these ethical dimensions of ACC contrasts with the current "muddling through" pattern of ACC debates, pointing toward radical new directions.

This article reflects on ethics, but the approach is not purely philosophical. Over its long career, the dominant forces guiding ACC have not been ethical discourses, but rather changes in everyday social structures, economic relations and political engagement. Ethical assumptions enter this discussion indirectly, emanating from popular notions about how current society really works. Perhaps the most striking trend, since the time in which Woodhouse wrote, has been to translate social welfare into broadly economic terms: to understand social action as principally a matter of self-interested calculation and exchange. This unmistakable twist in the meaning of society and "community" is equally the result of waning confidence in traditional political institutions to manage any rival measure of social welfare. Values have thus played a constant role in the halfcentury of ACC debates, even if the source of norms remains something of an enigma. In his day, Woodhouse steered the personal injury debate out of the legal realm and into the "social" realm. But just what kind of society did he imagine, and how was it connected to his key ethical principle of community responsibility?

\section{B Understanding Community Responsibility}

Woodhouse started from the broad surmise that social relations had changed substantially in New Zealand in the decades following World War Two. It was a time of growing national 
prosperity, integration of productive forces, advancing technology - and an increase in the scope and scale of uncompensated personal injuries: ${ }^{6}$

\section{COMMUNITY RESPONSIBILITY}

This first principle is fundamental. It rests on a double argument. Just as a modern society benefits from the productive work of its citizens, so should society accept responsibility for those willing to work but prevented from doing so by physical incapacity. And, since we all persist in following community activities, which year by year exact a predictable and inevitable price in bodily injury, so should we all share in sustaining those who become the random but statistically necessary victims. The inherent cost of these community purposes should be borne on a basis of equity by the community.

The change in social relations came down to an increase in complexity. Patterns of risk were no longer just interpersonal and linear. The aggregate increase in social prosperity carried with it the "statistically necessary" and "inevitable" consequence of serious injury for a small and random group of victims. Another aspect of complexity was the sequence of knock-on effects from personal injury, with consequent losses to family members, workplaces, and extended communities of interest: ${ }^{7}$

Community Responsibility: If the well-being of the work force is neglected, the economy must suffer injury. For this reason the nation has not merely a clear duty but also a vested interest in urging forward the physical and economic rehabilitation of every adult citizen whose activities bear upon the general welfare. This is the plain answer to any who might query the responsibility of the community in the matter. Of course, the injured worker himself has a moral claim, and further a more material claim based upon his earlier contribution, or his readiness to contribute to the national product. But the whole community has a very real stake in the matter.

Analytically, the causes of injuries were multiple, interactive and cumulative - not just in the workplace and on the highway, but across the many complex roles people play in all facets of their lives. Overall the causes are complex, operating on several levels; and so are the consequences, where an unexpected event, though entirely a part of modern living - like the rare side-effect from standard medications - may have a catastrophic impact on the victim and her entire family. Traditional common law had lost any claim to keep up with these developments, harking back to an era where causal patterns were transparent and linear, where relevant harms were foreseeable, and where actual losses could be readily contained and compensated. From this set of premises, Woodhouse found broad new responsibilities for the "community" where such dynamics were deeply embedded.

6 At [56].

7 At [5]. 


\section{Ignoring Community Responsibility}

The most intriguing mystery surrounding community responsibility is how such a distinctive principle has managed to exert so little influence during some four decades of ACC policy debates. To be sure, Woodhouse did his original job supremely well: his community responsibility principle cast fatal doubt on current tort law, and it was powerful enough to reassure stragglers that realistic alternatives could be found. But it had to be toned down in the protracted course of implementing ACC legislation, and with each decade its influence seemed to weaken. Admittedly, the tort law of the 1960s may have been an easy target, riddled with inconsistencies and anomalies, almost begging for some plausible substitute. But even this does not explain the readiness of policy makers to dilute the original components of community responsibility. Woodhouse had defined community responsibility within a distinctive model of social interaction, yielding a challenging set of ethical corollaries. By the early 1970s, this kind of social model was gaining acceptance in other fields of public life, notably in environmental policy and public health practice. But it was never embraced in the arena that received the Woodhouse Report - not by most lawyers or lawmakers, nor by social analysts concerned with injuries and compensation. In these fields, different social models began taking root in the 1960s, heavily influenced by formal styles of economic reasoning. These models brought their own compelling gloss to the notions of "community" and "responsibility", with quite different ethical implications.

In other countries, these same confounding currents slowed similar critiques of personal injury tort law, leaving New Zealand as the lone abolitionist jurisdiction in the common law world. Opposition took many forms, including resistance by those with vested interests in the old procedures (personal injury lawyers, but also certain plaintiff groups that had managed to game the system successfully). There was even a revanchist movement to rebuild traditional tort law on cramped moral principles that excluded social welfare calculations, borrowing selectively from the philosophies of Kant and Aristotle. ${ }^{8}$ But the most important challenge came from erstwhile partisans for law reform, who adopted a new economic idiom for engaging with social welfare. In academic circles this trend became known as "Law and Economics", which largely supported the deregulatory turn in public policy unfolding globally during the 1970s. All these changes were still inchoate at the time Woodhouse first wrote. But they were rapidly coalescing in the run-up to the first ACC legislation in 1972-1974. In such a fluid environment, even a principle as sharply defined as community responsibility could lose its edge.

\section{ANALOGUES OF COMMUNITY RESPONSIBILITY}

Woodhouse was not simply a lone voice. Although he worked independently, he articulated social/ethical principles that also resonated within the emerging environmental movement. What

8 Among many examples, see Ernest J Weinrib "Toward a Moral Theory of Negligence Law" (1983) 2 Law and Philosophy 37. 
Woodhouse saw as social interdependence was similar to notions of ecological interdependence, popularised in the 1960s by Rachel Carson, with antecedents in Aldo Leopold and Amos Hawley. ${ }^{9}$ The enigma surrounding community responsibility may be clarified somewhat by comparison with the development of environmental policies, both in New Zealand and globally. The moral urgency of environmental protection comes from the same matrix of causal complexity: in both areas there are unintended consequences built into the normal activities of an advanced industrial society. Harms to the ecosystem are difficult to predict, and they resist simple identification with discrete causes, but they are statistically inevitable and randomly allocated. In recent years, these same characteristics belong to the quintessential environmental policy challenge of climate change. There is also a striking economic similarity, in that both fields call for an accounting of real costs that fall outside the operation of existing markets. Sometimes called "external" costs, and also "social costs", it is the ethical task of public policy to see that these unpaid costs are remedied in some fashion. Their effects can sometimes be mitigated after the fact, but the larger policy goal is to prevent or reduce such unpaid costs occurring in the future.

\section{A Unpaid Social Costs}

One of the early environmental economists formulated these ethical implications in terms that anticipated the future Woodhouse principle. Writing in the 1950s, the German-American economist K William Kapp drew attention to social costs generated by the post-World War Two industrial economy, including pollution, personal injury, disease patterns and other unintended consequences, none of which were bargained for. He thus described: ${ }^{10}$

... an economy of unpaid costs, "unpaid" in so far as a substantial proportion of the actual costs of production remain unaccounted for in entrepreneurial outlays; instead they are shifted to, and ultimately borne by, third persons or by the community as a whole.

$\cdots$

The increasing use of the terms "environment" and "ecology" in recent discussions of social costs is to be welcomed, provided these terms are interpreted in a sense sufficiently broad to include not only the impairment of the physical environment but the impairment ... of all external conditions and influences affecting the life and development of human beings, human behavior, and hence society.

9 Rachel Carson Silent Spring (Houghton Mifflin, Boston, 1962). For a history of this earlier phase of environmentalism, see Philip Shabecoff Earth Rising: American Environmentalism in the 21st Century (2nd ed, Island Press, Washington DC, 2001).

10 K William Kapp The Social Costs of Private Enterprise (Schocken Books, New York, 1971) at 231 and ix$\mathrm{x}$. 
Kapp describes an interactive economy as generating unpaid social costs, imposing uncompensated burdens on specific people, which ultimately fall on "the community as a whole". From here it is a very short step to Woodhouse's community responsibility principle: ${ }^{11}$

Just as a modern society benefits from the productive work of its citizens, so should society accept responsibility for those willing to work but prevented from doing so by physical incapacity. And, since we all persist in following community activities, which year by year exact a predictable and inevitable price in bodily injury, so should we all share in sustaining those who become the random but statistically necessary victims. The inherent cost of these community purposes should be borne on a basis of equity by the community.

\section{B Links to Public Health}

Another contemporary echo of Woodhouse's community responsibility principle can be found in the field of public health, which developed new research tools for analysing social complexity, leading to the discovery of hidden social costs. ${ }^{12}$ Within New Zealand, public health researchers sought to document Woodhouse's claim that the nation as a whole faced a substantial toll of uncompensated personal injuries. By 2003 researchers assigned an actual dollar figure to this toll: somewhere around NZD 6-7 billion per year. ${ }^{13}$ These are real losses, accruing annually, with the burdens falling on individual victims, their families and onwards through social channels of interdependence. As Woodhouse argued, such a burden far exceeds the goals and capacities of the common law: this was clearly a social problem, not a legal problem.

Around the world, in recent decades, public health has applied its powerful research methods to elaborate the social interdependence model used by Woodhouse. Public health has more sophisticated tools than either law or economics for navigating these complexities. It deals routinely with interactive causes, multiple agents and dynamic environments, all of which presented insuperable challenges for the old common law doctrines of liability. Within this complex environment public health confirms many of the harms Kapp identified as "unpaid social costs", dealing with real physical events themselves, and not just the internalised market transactions studied by mainstream economics. And like Woodhouse, public health sees the leading policy goal

11 Woodhouse Report, above n 1, at [56].

12 For an overview, see Robert Beaglehole and Ruth Bonita Public Health at the Crossroads: Achievements and Prospects (2nd ed, Cambridge University Press, Cambridge, 2004).

13 Relevant studies were conducted by the respected Injury Prevention Research Unit at Otago University. See for example SCR Stephenson, JD Langley and MJ Trotter Impact of Injury in New Zealand (2nd ed, University of Otago, 2005). A 2012 study gave the figure as NZD 10.4 billion: New Zealand Injury Prevention Strategy The New Zealand Injury Prevention Outcomes Report - June 2012 (Accident Compensation Corporation, 2012) at 7. These and other relevant reports are no longer available on the website for the New Zealand Injury Prevention Strategy (see below at n 15). 
as preventing future harms (primary prevention), followed by mitigation of past harms through rehabilitation and, lastly, compensation.

ACC implementation has largely ignored the expansive public health implications of community responsibility by remaining heavily focused on the statutory compensation function. ${ }^{14}$ To be sure, rehabilitation services are included in entitlements as an appropriate medical response to personal injury. Controversies often arise over the administration of these benefits, including the complaint that the Accident Compensation Corporation (Corporation) uses rehabilitative services in a budgetsaving way; as a blunt instrument for ending compensation for those claiming long-term incapacity. There are also periodic news exposés about rehabilitative therapists who have allegedly defrauded the system. Overall, ACC policy debates tend to address rehabilitation in strict relation to controlling operating budgets.

At an exceptional moment in 2003, public health perspectives stood behind the creation of a New Zealand Injury Prevention Strategy (NZIPS). This initiative came through ministry planners, rather than from legislation. ${ }^{15}$ NZIPS was a rare instance where ACC practices expanded to meet challenges contained in the original community responsibility principle. Community responsibility assigns responsibility to New Zealand society as a whole to invest in prevention, even more than compensation, to reduce the toll of personal injury. In practice, the impact of NZIPS proved to be minimal, and it was disestablished in 2013. Despite some highly professional planning, the strategy was economically driven in a narrow sense, focusing on preventing types of injuries that place large financial burdens on the Corporation budget - important but discrete problems like back injuries, serious rugby injuries and accidental drownings. By contrast, from the ethical perspective of community responsibility, the relevant cost consideration is not to reduce the Corporation's operating budget, but rather to reduce the much larger social toll of personal injury, advancing unchecked into the future. This toll represents real costs - they are Kapp's unpaid social costs, which are left as real burdens for the statistically inevitable victims and their families.

\section{THE MYSTERIOUS DECLINE OF COMMUNITY RESPONSIBILITY}

Despite this rich background, the mystery surrounding the eclipse of community responsibility still remains unsolved. Back in 1967 Woodhouse articulated community responsibility forcefully, laying out all the implications: describing a new institutional structure for addressing the burdensome toll of personal injury. It was not just a rejection of the common law system. Instead

14 William W Vosburgh argued that it was politically easier to implement the compensation side of ACC than prevention: William V Vosburgh "Primary Prevention, Priorities, and Implementation: The Case of the New Zealand Accident Compensation Act" (1982) 13 New Directions for Mental Health Services 73.

15 The Strategy was disestablished in 2013, but a skeleton webpage remains for the record: Accident Compensation Corporation "New Zealand Injury Prevention Strategy (NZIPS)" (9 April 2014) <www.acc.co.nz>. 
Woodhouse laid out an alternative framework, an amalgam of social modelling and ethical reasoning, as a powerful measure of how and why the tort system was failing New Zealand society. His approach was similar to frameworks that would soon emerge for environmental policy in many countries around the world. Moreover, it anticipated the powerful research apparatus of public health, with links also to what an earlier generation of economists referred to as "unpaid social costs". Why then has this distinctive principle been effectively muted across five decades of ACC policy debates?

\section{A Economic Issues}

The most accessible answer to this mystery is that the programme laid out by Woodhouse would be too costly. Perhaps it should be done, under ideal conditions, but there is not enough money in the pipeline. This explanation can find immediate support in the New Zealand policy dialogue, even though it meant ignoring the core ethical challenge framed by community responsibility. The whole point of community responsibility is that the costs of personal injury have already been paid falling on victims and spreading throughout their networks. Although these costs do not appear, as such, on any corporate or government balance sheet, they are nonetheless real. The community's responsibility is to redress a skewed distribution of social costs, already incurred, whose very randomness augments the burden shared by everyone. Seen as a community of risk sharing, New Zealand could not continue absorbing the toll of injury costs. In responding, the community as a whole must provide funding for remedial programmes. From one economic standpoint, programme costs would more than pay for themselves if they are understood to reduce social costs. But making this leap would become the decisive political barrier for the emergence of Woodhouse's community. As we shall explore in a moment, Woodhouse had already anticipated policy objections based on programme costs. His strategy prevailed in the fact that ACC was ultimately adopted, but the demurral on programme costs was never silenced.

\section{B Academic Turn to Welfare Economics}

In another historical coincidence, these affordability debates found a broader base of support in the arcane academic field of Law and Economics. Ideas from this movement showed up in New Zealand as early as the 1969 White Paper, which offered the first blueprint for legislative implementation of the Royal Commission Report. It was in this White Paper and surrounding deliberations that proponents of the ACC scheme began to soften the hard edges of community responsibility, importing concepts of market efficiency that would obscure Woodhouse's focus on social costs. ${ }^{16}$ During the 1960s, an American legal expert on torts was reshaping the ethics of tort reform by importing the dryer norms of welfare economics. According to Professor (now Judge) Guido Calabresi, the proper goal for public policy was neither to compensate injured people nor to

16 "Personal Injury: A Commentary on the Report of the Royal Commission of Inquiry into Compensation for Personal Injury in New Zealand" [1969] IV AJHR H 50 [White Paper] at [205]. 
reduce future accidents, as such. Rather the goal - to put it precisely - was to limit the scale of future accident prevention in accordance with a calculus of economic efficiency. ${ }^{17}$ From an ethical point of view, there was no other policy standard worth considering. In short, preventing future accidents must not be pursued without limit; it may be cheaper to society as a whole (and thus better) to allow some accidents to happen. (Needless to say, the balance sheets entering into this efficiency calculation still exclude the unpaid costs studied by Kapp.) While this may seem like a complicated balancing act, proponents seemed to relish the intellectual challenge - all of it unfolding at the level of axioms and hypothetical models. As it trickled down to ordinary policy debates in New Zealand and elsewhere, the message was much simpler: "everything in moderation; don't overspend".

When it comes to compensating people already injured, Calabresi agreed that the tort system itself was poorly designed for this purpose, conceding much of what Woodhouse and others had painstakingly shown. ${ }^{18}$ But in reforming that system, Calabresi's chilling advice was to limit compensation to precisely those cases where payments would promote efficient levels of future accident prevention. One need not be distracted by the personal needs or deserts of the injured victim. Calabresi noted correctly that purely moral claims to compensation were not recognised by common law - which was historically content to leave the burden of accidents with victims, unless some proper defendant could be clearly identified.

In Calabresi's defence, he might have said that anyone worried about personal injury could always hedge by purchasing insurance, at whatever level of compensation they preferred. Personal safety was best understood as a commodity, and thus could be removed altogether from the customary moral calculus. The community of potential accident victims should each consider purchasing individual, first-person insurance policies. In such a community, sovereign consumers will decide, in the aggregate, how much safety and how much future prevention they want. The only question worth asking was how the efficiency criterion could be made operational in a chaotic common law system. If there were any other ethical issues left over, Calabresi concluded, they should be exiled beyond the framework of rational policy debate. ${ }^{19}$

\section{Funding ACC Programme Costs}

Woodhouse was aware of these academic developments and thought their irrelevance should be plain enough to advocates of community responsibility. As it turned out, he underestimated the attraction of these ideas, even as intellectual cover for more practical interests in lowering ACC programme costs. But he had fully anticipated the local argument that there was not enough money

17 Guido Calabresi The Costs of Accidents (Yale University Press, New Haven, 1970).

18 At 5 .

19 At 292 . 
to fund a new comprehensive ACC. As Chair of the Royal Commission, he made sure that one of its members was an accountant; and the Report deals extensively with cost estimates. ${ }^{20}$ On a strategic level, his calculations were pragmatic: if he could fund the new scheme mostly with existing revenue streams (insurance premiums currently being paid for workers' compensation and motor vehicle insurance), then the community could begin to discharge its responsibilities with only few adjustments. After the abolition of tort, there would be no returning to common law; the logic of community responsibility would assert itself more boldly over the long run.

\section{Policy Hesitations on Implementing Community Responsibility}

Thus Woodhouse himself proposed certain ways that community responsibility might be eased into immediate practice. Looking ahead to the future, community responsibility should rightly apply to all kinds of personal incapacity - whether by injury or disease (a distinction that disappears in the matrix of complex causality). But Woodhouse expected this grander logic to unfold only with the passage of time. ${ }^{21}$ There were good reasons to expect the momentum to build. In a deeply interdependent society, once the community has discovered its interdependence, and has coalesced around it, public policy can move gradually and inexorably toward the realisation of community responsibility. In retrospect this may seem like magical thinking. But it furnishes an important clue to the whole mystery of community responsibility: beyond the economic challenges, there were even greater political requirements for establishing a new ACC scheme. The facts of social interdependence, when brought to the surface, would need to generate a new spirit of solidarity, with a fresh assertion of political will. No such breakthrough occurred in New Zealand.

Among the signs that community responsibility would not be self-implementing were the reports of two subsequent Royal Commissions: on Social Security (1972) and on Social Policy (1987-1988). The Social Security Royal Commission felt pressure coming from community responsibility, which contained a prima facie argument for upgrading some types of social entitlement. As Woodhouse noted, the matrix of interdependence behind personal injuries held implications for disease-based disability and sickness. But the Social Security Royal Commission drew a firm line between the domain of accidents (keeping it genealogically pinned to its common law antecedents) and other entitlements. It accepted none of the "responsibility" language embedded in community responsibility, including the notion that the sick or disease-disabled should be rehabilitated for the sake of the community as a whole. ${ }^{22}$ By the time the Social Policy Royal

20 See Woodhouse's comments on Geoffrey Parsons in his 2007 informal remarks at an Auckland conference: Owen Woodhouse "ACC Anniversary - 13 December 2007" (paper presented at Accident Compensation 40 Years On: a Symposium to Celebrate the Woodhouse Report, Auckland, December 2007).

21 Woodhouse Report, above n 1, at [17].

22 New Zealand Royal Commission of Inquiry into Social Security Social Security in New Zealand: Report of the Royal Commission of Inquiry (1972). For an analysis of the Social Security implications of ACC, see 
Commission made its report, the Law and Economics movement had popularised norms for limiting regulatory prevention - omitting to recognise ethical dimensions of unpaid social costs, where random elements of the community had already paid a heavy price that never showed up in marketplace balance sheets. ${ }^{23}$ The Chairs of these two Royal Commissions might have sympathised with ACC itself, but they saw no reason to extend community responsibility beyond the narrow scope of personal injury compensation.

\section{E Social Contract Theory}

There were additional signs that the inchoate community invoked by community responsibility was losing political traction, even in the arguments of ACC's most ardent defenders. By the 1990s, a new and simpler ACC moral foundation gained attention - the notion of a social contract. The ethical import of such a contract comes from the metaphor of individual will rather than social solidarity. This contract was held to be an agreement by beneficiaries to give up their right to sue for personal injury damages, in exchange for benefits that would approximate the damages offered in a well-run tort system. For both sides, the bargain was motivated by economics (sparing the macroeconomy the costs of administrative waste in tort), backed by the thin moral guarantee of a handshake between consenting parties. One can look in vain in the Woodhouse Report for any hint of this bargain. As moral backing for the ACC scheme, it fragments community responsibilityw's concept of community. It replaces the social model of interdependence and solidarity with the market metaphor of a bargain between interest groups. As such, it captures more candidly the flavour of ACC policy debates, especially as they echoed through the contentious 1980s and 1990s. By this point, ACC policy had turned into a familiar battle between beneficiary groups (the injured) and funding groups (employers, drivers, and, at the margins, taxpayers). The controversy was how generous benefits should be, and how strict to make the criteria of entitlement. The contractfulfilment argument had difficulty holding back the countervailing cost-saving arguments. It was, indeed, a last-ditch turn to ethics in a policy marketplace where the common currency was conserving cost.

\section{THE STRUGGLE FOR A NEW COMMUNITY}

Despite the clarity Woodhouse achieved in formulating community responsibility, in retrospect the problems of political implementation seem entirely predictable. Although strikingly framed as a hybrid scheme borrowing from both law and social welfare, ACC implementation faced the same strong headwinds as other social welfare programmes in developed nations. As German sociologist

Jane C Kronick, Miriam G Vosburgh and William W Vosburgh "Changing Principles for Disability in New Zealand" (paper presented to IX World Congress of Sociology, Uppsala, August 1978).

23 New Zealand Royal Commission on Social Policy A Fair and Just Society (1987); and New Zealand Royal Commission on Social Policy The April Report (1988). Recommendations for ACC are found in The April Report vol 2 at 759-760 and vol 3 at 573-607. 
Claus Offe observed in the 1980s, the disillusionment with welfare principles in social-democratic societies could be traced to a decline in the shared sense of solidarity. To restore that sense, wrote Offe: ${ }^{24}$

... the critical sociological variable is some notion of commonality of interest and fate, of 'sameness,' or

a sufficiently binding conception of a durable collective identity, which is the ultimate resource that

keeps cooperation intact beyond its initial phase.

By providing exactly this kind of social conception, community responsibility might have pushed forcefully against the trend. But instead of injecting new moral purpose into policy debates, community responsibility went into eclipse. For still deeper insight into this mystery, we must go back even further in time to the American philosopher John Dewey, in a classic series of lectures, published in 1927 as The Public and Its Problems. ${ }^{25}$

\section{A Dewey and the Problem of Community Self-Governance}

Although writing nearly a century ago, Dewey was interested in the normative changes facing societies that had passed through sudden growth spurts. In the case of the United States, the late19th century surge in industrial development prompted a shift from largely rural forms of life to denser urban environments. Strong ties of families and local communities were losing their grip, giving way to the weaker ties of growing urbanisation, factory employment, mass consumption and the population "melting pot" that transformed American life by the 1930s. If solidarity was an habitual norm for small-scale American society, what would happen to feelings of solidarity in this new matrix of complex ties in the initial stages of industrialisation? In particular, Dewey asked how political institutions would fare in a period when interest-group politics was eroding the traditional notion of a unified public interest.

Rather than looking backward with nostalgia, Dewey was searching for new concepts and political forms that would allow a richer, more complex "public interest" to emerge under changing social conditions. He found a working definition for this modern "public", combining structural and normative elements; but he cautioned (in 1927) that it was still inchoate, and would, in fact, face great difficulty breaking into the full light of day. Below the surface of modern life there was a new kind of "public" waiting to emerge, but it would likely remain "in eclipse" until new concepts gave voice to this modern form of solidarity. These concepts would need to generate more intense norms of reciprocity, leading to new political initiatives. The public's problems are "political" in the sense that self-government remains an unfulfilled dream until such time as the hidden public comes to recognise itself, and to embody its awareness in public policy. His book concluded, somewhat

24 Claus Offe "Democracy Against the Welfare State?: Structural Foundations of Neoconservative Political Opportunities" (1987) 15 Political Theory 501 at 523.

25 John Dewey The Public and Its Problems (Henry Holt, New York, 1927). 
pessimistically, that this "search for the public" might continue indefinitely, in an age where social identity was busily fragmenting.

Dewey's lectures offered a modernist notion of "the public", putting aside prior philosophies and standard definitions, while taking an empirical perspective on the social relations of his day. He defined his hidden "public" as an inchoate network of persons affected by the "indirect consequences" of private transactions. ${ }^{26}$ Such a network, composed of non-bargained relationships that go beyond market transactions, reminds us of Kapp's discovery of "unpaid social costs" in the 1950s, at the beginning of the environmental movement. And of course it anticipates the principle of community responsibility elaborated by Woodhouse in the 1960s. Dewey's analysis directs attention to the key political demand in community responsibility: that mutual responsibility requires active self-government by the interdependent community. The challenge might first present itself as economic - but the core problem is political.

All these concepts share a family resemblance, which in our own time includes, first and foremost, the politics of global climate change. The template for an interdependent public goes back to Dewey, who correctly noted the problems of reconciling modern forms of interdependence with the discrete individualism of market transactions, political interest groups and thin moral obligations derived from contract. ${ }^{27}$ The community of all those "indirectly affected" lies beneath the surface of common transactional forms - still waiting to emerge. Woodhouse's community responsibility principle expresses this distinctive ethics of reciprocity. In a modern society, solidarity is no longer based on kinship, archaic legal duties, contracts or market warranties; it comes from an interactive matrix like the one Woodhouse posits. One thing we all share in common is our exposure to the risks of modern living. There is a community, as Woodhouse describes it, of participants in a system that generates "statistically inevitable" risks, falling randomly on some members of that community. The fact that unpaid costs have already been incurred requires a full and urgent response from all who participate in this risk-bearing community. Implementing that response in effective policy is vital to the political ideal of self-governance.

\section{$B$ Defining the Risk Community and Its Responsibilities}

There were other notable attempts to address the policy implications of Dewey's "public and its problems". Coming from the same social-democratic context as Woodhouse, the British welfare theorist Richard Titmuss was another eloquent voice ready to speak on behalf of Dewey's emergent public. Writing in the 1980s, Titmuss described a three-step progression of social programmes in the post-World War Two industrial era. He called the first two steps the "residual welfare" model and the "industrial, achievement-performance" model. The former includes the Thatcher and Reagan

26 At $15-16$.

27 At 141. (These issues were raised not only in the United States, but were also explored in classic studies by Émile Durkheim, Georg Simmel and Ferdinand Tönnies.) 
safety-net approach to welfare, under which the only public role is to address temporary failures in the dominant social institutions of families and markets. The second model accepts need-based welfare programmes as permanent adjuncts to industrialised economies, and thus as components of politically managed capitalism. Under both approaches, state-administered benefits are limited to selective groups near the bottom of the economic scale. Their purpose is to sustain the lower strata, to keep them functioning in a social system defined primarily by market processes.

By contrast, Titmuss' third "institutional-redistributive" model holds reciprocal values similar to the community responsibility principle. This model rests on: ${ }^{28}$

... theories about the multiplier diswelfare and disrupting effects of change, industrial, technological, social, and economic; and in part on a conception of social justice which sees man not only as an individual but as a member of groups and associations.

The goals for public policy, under this model, are:29

... to promote integrative values, to prevent future diswelfares, to penetrate economic policies with social welfare objectives, and in all these ways to bring about a redistribution in command over resources over time.

(He might well have added Dewey's self-government goal.) This model "challenges different societies at different stages of development ... to determine a particular infrastructure of universalist services". ${ }^{30}$

The potential community in community responsibility would need to build political solidarity on the common experience of generating risks, of bearing and sustaining risks, and of remediating future risks. This Woodhousian definition is a modernist concept, which must somehow emerge and declare itself, but without exploiting traditional sentiments and symbols that united earlier communities around the veneration of gods, kings or kin. The simple idea that "we are all in this together" struggles to reach beyond a small subset of the electorate - today more likely to be found in the environmental lobby than the ACC lobby. In global terms, the most important test shaping up for this hidden community will be enacting policies for combatting global warming. One cannot yet see how a global risk community will discover itself, let alone govern itself, with sufficient time to make a difference. Lessons from the New Zealand risk community, even with the rhetorical boost from community responsibility, suggest we must follow Dewey's caution.

28 Richard M Titmuss "Developing Social Policy in Conditions of Rapid Change" in Brian Abel-Smith and Kay Titmuss (eds) The Philosophy of Welfare: Selected Writings of Richard M Titmuss (Allen \& Unwin, London, 1987) 254 at 263-264.

29 At $263-264$.

30 At $263-264$ 


\section{THE ECLIPSE OF SOCIAL COST THEORY}

A mystery parallel to the eclipse of community responsibility is the fact that Kapp's post-war theory of "unpaid social costs" was thoroughly buried by the 1970s. His theory was not so much analysed and rejected as simply bypassed by the new idioms of welfare economics. Along with Calabresi, a seminal essay by Ronald Coase on "The Problem of Social Cost" (which never mentions Kapp or anyone in that social-cost tradition) offered an alternative discourse, leaving Kapp in the shadows. ${ }^{31}$

The rise of welfare-economic models in the late 1960s pre-empted new policy responses to the problems of risk communities. This shift was not some evil conspiracy, but reflects an historic retreat by the state from its stewardship of social relations and social justice. In the field of accidents - not just in New Zealand, but globally - political institutions found themselves unable to manage complex risk factors that were already evident by the $1950 \mathrm{~s} .{ }^{32}$ As the environmental movement surmised in the 1960s, continual advances in scientific knowledge were expanding the frontiers of uncertainty, uncovering a host of ill-defined risk factors at the margins of economic progress. At the time, it was reasonable to think that modern inequality resulted as much from the random distribution of risk as from the distribution of wealth or income. This retreat into welfare economics can be seen as a rearguard effort, suspending the renegotiation of new social responsibilities.

The fate of Kapp's theory shares important features with the policy debates surrounding ACC. The erosion of community responsibility stems ultimately from the political struggle of the Woodhousian risk community finding its policy footing. It is a struggle for self-recognition and selfgovernance. The roots of failure were hard to discern, as New Zealand policy debates gradually abandoned the ethical dimensions of community responsibility, instead importing market metaphors from the Law and Economics movement. These concepts entered the mainstream rapidly after a test run in the important 1969 White Paper on ACC. And, indeed, they had already been used by Terence Ison in his much admired 1967 book The Forensic Lottery - which the Woodhouse Commission had consulted in manuscript, before creating a different language in community responsibility. ${ }^{33}$

31 RH Coase "The Problem of Social Cost" (1960) 3 Journal of Law and Economics 1.

32 For a classic statement of this position, see Ulrich Beck Risk Society: Towards a New Modernity (Sage Publications, London, 1992) (a translation of Risikogesellschaft: Auf dem Weg in eine andere Moderne (1986)).

33 Ison, above $\mathrm{n} 4$, at 58. 


\section{A Institutionalist Theory of Social Costs}

K William Kapp's theory of social costs falls within the American Institutionalist school of economics, which Kapp encountered as a refugee from Germany after World War Two. ${ }^{34}$ His research covered both developed and developing societies, based on his own extensive fieldwork. In his 1950s writings on social costs, Kapp identifies a specific kind of social harm marked by five conditions: (1) these harms are "normal and typical" phenomena in industrial societies, documented retrospectively through empirical study, at least at the statistical level (for example, epidemiology); (2) they are causally complex (for example, gradual process injuries or multi-factor environmental disease); (3) they are embedded in relational networks of concrete persons and things, and are not mere functions of subjective attitudes; (4) their complexity and relational structure place them beyond the scope of micro-economic calculation (outside the bounds of neo-classical rationality); and (5) they are imposed without contractual specification on parties to an exchange (for example, newly identified occupational diseases), or are shifted to people and environments lying outside the exchange transaction (for example, victims of second-hand smoke).

\section{$B$ The Neo-Institutionalist Alternative}

Kapp's theory of social costs was ultimately eclipsed by "neo-institutionalist" alternatives, of which the best known is the famous Coase essay. ${ }^{35}$ Coase and his neo-institutionalist colleagues never directly challenged Kapp's model, but simply reframed the discussion of social costs within a different conceptual idiom. Kapp identified social costs with concrete harms befalling real people. The neo-institutionalists treated them as accounting data in real or hypothetical exchanges - harms seen as depersonalised, calculable sums, the residue of failed bargains between potential exchange partners. (Adam Smith would have called this a shift from use values to exchange values. $)^{36}$ In a Coasean world it is impossible to say - putting aside the prevailing property regime - whether the polluter is harming the pollutee, or the other way around. The exchange relationship (real or hypothetical) always presumes this analytical symmetry, and neo-institutionalist policy concentrates on restoring that neutral balance in the face of market imperfections.

These different conceptions of harm are decisive for designing a public policy scheme for personal injuries and preventable illness. In Kapp's world, where personal injury is part of the unpaid social costs of modern industrial society, the appropriate response is a comprehensive public

34 There has been a recent revival of scholarship on Kapp and his intellectual context. See Sebastian Berger "The Making of the Institutional Theory of Social Costs: Discovering the K. W. Kapp and J. M. Clark Correspondence" (2013) 72 American Journal of Economics and Sociology 1106. Kapp's works are in the process of being edited and reissued. More established figures in American Institutionalist Economics include John Maurice Clark and John R Commons.

35 Coase, above n 31 .

36 Adam Smith An Inquiry into the Nature and Causes of the Wealth of Nations (1776) book I at ch 4. 
scheme devoted to prevention, rehabilitation and compensation - anticipating the logic of community responsibility. In contrast, neo-institutionalist policy creates shadow-markets to reduce costs of potential bargaining, thereby allowing market forces to find the right level of compensation and prevention. In this bargain-centred response, what we might call the "market public" remains indifferent between the plight of the industrial disease victim and the plight of the factory that must mitigate exposures to carcinogens, assuming impediments to potential bargaining have been removed. Bargainers themselves can address any subjective uncertainties by purchasing private insurance.

For Kapp, social costs are "normal and typical" consequences of transactions common to industrial economies. These costs cannot be forced back into the bottle of discrete exchange or bargaining relationships. Social costs can afflict exchange partners but also, more importantly, those outside the scope of exchange. In Kapp's words: ${ }^{37}$

[A] substantial proportion of the actual costs of production remain unaccounted for in entrepreneurial outlays; instead they are shifted to, and ultimately borne by, third persons or by the community as a whole.

These unpaid social costs have financial, environmental, medical, psychological and cultural dimensions - and they are also notorious for reaching into future generations of victims.

The Coase article can be seen, in retrospect, as a pioneering essay operating under a new economic idiom, presupposing a new kind of community. Borrowing from the fashionable academic embrace of general equilibrium economics (though without displaying any of its mathematical tools), Coase reflected a growing skepticism about public insurance and democratic authority. In the language of welfare economics, value and legitimacy come from the sovereign preferences of individual consumers. At the level of ethics, there was simply no way to calculate the kinds of harms posited by Kapp (and later by Woodhouse). ${ }^{38}$

\section{Employer Levies under ACC}

The neo-institutionalist preference for market remedies caught hold in New Zealand during the 1980s. This shift can be seen most clearly in the turn away from expanding the grounds for entitlements, and toward a stricter allocation of programme costs among private funders of the

37 Kapp, above n 10, at 231.

38 Calabresi was likely the only neo-institutionalist to mention Kapp by name. He conceded the drift of Kapp's work but complained that it would be too "costly" to bring it into a bargaining framework (meaning high "transaction costs" in Coase's Delphic phrase). But the gap is one of quality rather than quantity, where we are dealing with two incommensurable modes of calculation. For Calabresi on Kapp, see Guido Calabresi "Some Thoughts on Risk Distribution and the Law of Tort" (1961) 70 Yale LJ 499 at 532-533. 
scheme. ${ }^{39}$ Much discussion was devoted to setting differential levies for separate industries - and individual companies - based on the personal injuries they "caused" (a concept alien to Woodhouse). But the ultimate goal of neo-institutionalist policy was best articulated by the New Zealand Business Roundtable. ${ }^{40}$ They argued that injury burdens should be managed on the funding side, always and exclusively, through institutions of market exchange. Uncompensated harms of personal injury should be addressed by creating private markets for insurance and risk management. Government mandates that do not pass the test of emulating market systems should be treated with the greatest scepticism. From this perspective, it is less important to compensate past injuries than to treat yesterday's events as financial signals to today's risk managers, who can then decide how much money to invest in tomorrow's prevention. Taken to the extreme, this point of view considers the whole public compensation scheme as an anomaly, since injured people should already have purchased first-party insurance. Going forward, society should strive to achieve only the level of prevention it is willing to pay for, as determined by market mechanisms. Risk reduction is an investment decision best delegated to individual companies and persons.

The contrast is plain between this value philosophy, stated in its purest form, and the Woodhouse community responsibility principle. Woodhouse did not assign injuries, via causation, to specific risk-creating activities by particular market actors. He maintained that all risk-bearing activities were interdependent, and that ACC programme costs for compensation and prevention should be funded primarily from general taxation. ${ }^{41}$ As a practical matter, he relented by accepting existing funding streams from workers' compensation premiums and motor vehicle insurance. The eclipse of community responsibility can be seen most clearly in the long and bitter history of ACC funding disputes. The ethical dimensions of community responsibility were lost in acrid debates about who should pay the price, when someone else might have caused the harm. The script for these discussions was inspired by Calabresi and Coase, coming with the eclipse of Kapp.

\section{THE FINANCIALISATION OF PUBLIC POLICY}

In practical discussions of ACC policy, the market allocation model has pushed aside the community responsibility principle. Some of this is just old-fashioned self-interest, in the scrum where ACC payers seek to lower their levies, on the grounds they should not cross-subsidise others who truly cause accidents. Levy payers confront each other, and they confront those entitled to ACC

39 These changes can be traced in the Accident Compensation Act 1982, and the intriguingly named Accident Rehabilitation and Compensation Insurance Act 1992. (Both were repealed and replaced by the Accident Compensation Act 2001 and subsequent amendments.) The 1992 legislation was clearly a bridge to the kinds of proposals best articulated by the New Zealand Business Roundtable.

40 See New Zealand Business Roundtable "Submission to the Law Commission on the Review of Accident Compensation" (December 1987).

41 Woodhouse Report, above n 1, at [314] and [467]. At [490], Woodhouse noted that "there will be no place for special arrangements or for 'contracting out'". 
benefits, armed with their own individual safety records and profitability charts. This is obviously a different community from the interdependent risk-bearers defined by community responsibility. The ACC levy system imagines a world in which the risks of modern living have been fully reduced to financial terms, ready to be negotiated in market transactions. Although increasingly complex, ACC funding formulas cannot keep up with all the claims about cross-subsidisation and distorted economic incentives.

We are closer to solving the enigma of the disappearing community responsibility principle. Of course, it has not disappeared from the printed page, nor from the heartfelt advocacy of ACC proponents. It still finds support in its family resemblance to other concepts, notably environmental protection. Nonetheless, its effective disappearance signals the rise of different concepts of community, primarily market communities that are united - not politically - but in exchange. The fate of community responsibility can be understood in a broad political context, global in scope, where political deliberation has yielded to economic calculation - on its way into the portfolios of financial experts.

A recent monograph has examined this shift over the past four decades. In her empirical study of American public policy, including the rise of financial institutions for economic governance, political scientist Greta Kippner has updated the classic predictions of sociologist Daniel Bell, who diagnosed the turn to finance in developed countries as the result of a political legitimation crisis. Outsourcing political choices to market czars gained momentum in the 1970s, in the face of tumultuous global economic cycles, when politicians lost confidence in their ability to steer the macroeconomy using classic Keynesian tools - and the public lost confidence in their political leaders to manage crises on behalf of the community as a whole. As Bell remarked, democratic governance needs a public philosophy to validate collective decisions about the distribution of wealth. Bell's point would apply equally to decisions about the distribution of risk, the primary mission of ACC.

As Kippner notes: ${ }^{42}$

... markets do not supply their own normative foundations - as Bell wrote, "The market is a mechanism, not a principle of justice" ... In the financialization of the economy, policymakers would find an exceptional resolution to the various policy dilemmas they confronted in the guise of social crisis, fiscal crisis, and legitimation crisis of the state ... Traveling a further distance from the political, problem areas may migrate from governmental or non-governmental publics to the private realm of domestic deliberation and consumer choice. Relegated to this realm, problems are still subject to human decision ... but no longer subject to public scrutiny and deliberation.

42 Greta R Kippner Capitalizing on Crisis: The Political Origins of the Rise of Finance (Harvard University Press, Cambridge (Mass), 2014) at 141, 144 and 146. Her interlocutor Daniel Bell's key work, for these purposes, is Daniel Bell The Cultural Contradictions of Capitalism (Basic Books, New York, 1976), republished in a 20th anniversary edition (20th anniversary ed, Basic Books, New York, 1996). 
Along with Daniel Bell in the 1970s, Kippner's study echoes Dewey's haunting analysis of the public in eclipse. Politics as usual cannot serve the interdependent community of community responsibility, nor solve the problem of unpaid social costs, without "a public philosophy to guide decisions about distribution." The turn to markets, and especially to financial markets, says Kippner, has "allowed policymakers to shield themselves from responsibility for unfavourable events", ${ }^{43}$ although their luck (and ours) may be running out. The unintended results of conducting economic, fiscal and social policy through financial institutions includes the prospect of credit crises, asset bubbles and their inevitable strain on communities - measured as conflict rather than people pulling together.

Not everyone sees this trend in a negative light. The irrepressible Robert J Shiller continues to advocate for the creation of new global financial instruments as a way to unleash the market for managing the most significant risks of our time: serious earthquakes, global warming and pandemic diseases. ${ }^{44}$ The wisdom of the market will decide when and how to invest in combatting, preventing or mitigating these events. Shiller is less clear on the backup regulatory regime such new instruments would require, or what guarantees would come from outside the financial system in the event of market meltdown. He does not deal with the extremes, but sees finance as the best (because it is the only) available institution for addressing modern problems of risk. It may be a hollow claim. And in any case, it is unlikely to be implemented anytime soon.

If there remains some enigmatic aspect of community responsibility untouched in these reflections, it may be the surprising fact that community responsibility is still with us, a half-century after it was created. And while its persistence may have become a ritual, there is something about these two strong words that we cannot finally do without. It still seems true that "community" goes deeper than joining a group of consumers. And there must be something more to "responsibility" than simply and always honouring one's bargains. Woodhouse may have been onto something when he opened his Report with the grim reminder about the bedrock toll of personal injury. ${ }^{45} \mathrm{He}$ tried to connect these hard facts to a new policy regime, even if we have since lost the thread. But community responsibility retains a bewitching quality, beckoning a future community to find its own voice. The ongoing social problem of personal injury has clearly not been solved. What Woodhouse said in 1967 remains true today: "Such a fragmented and capricious response to a social problem which cries out for co-ordinated and comprehensive treatment cannot be good enough."46

43 Kippner, above n 42, at 147.

44 Robert J Shiller The New Financial Order: Risk in the 21st Century (Princeton University Press, Princeton, 2003). A more accessible version of his theory is Robert J Shiller Finance and the Good Society (Princeton University Press, Princeton, 2012). In 2013, Shiller was awarded the Nobel Prize in Economics.

45 Woodhouse Report, above n 1, at [1].

46 At [1]. 
For new generations contemplating ACC and the host of puzzles surrounding it, Woodhouse keeps the challenge open: ${ }^{47}$

The rate at which social institutions and ideas are being turned upside down is not merely dramatic - it is accelerating every year in a fashion which demands a great deal of mental energy to keep pace. It cannot be good enough, therefore, to adjust merely to the contemporary needs. Some deliberate attention should be given to the foreseeable demands of the years immediately ahead. And if there seem to be a weight of tradition against change, at least it is worth remembering that the apparent heresies of one generation become the orthodoxies of the next. The ultimate validity of any social measure will depend not upon its antecedents but upon its current and future utility.

47 At [33]. 